\title{
Determination of Riociguat by Oxidative Coupling Using Visible Spectrophotometry
}

\section{GIRI PRASAD GORUMUTCHU1, VENKATA NADH RATNAKARAM ${ }^{2 *}$ and SIREESHA MALLADI ${ }^{3}$}

1Department of Chemistry, Acharya Nagarjuna University, Nagarjuna Nagar-522510, India.

${ }^{2}$ GITAM University - Bengaluru, Karnataka-562163, India.

${ }^{3}$ Department of Science and Humanities, Vignan's Foundation for Science,

Technology and Research, Vadlamudi-522213, India.

*Corresponding athor E-mail: doctornadh@yahoo.co.in

http://dx.doi.org/10.13005/ojc/35Specialissue107

(Received: December 13, 2018; Accepted: February 05, 2019)

\section{ABSTRACT}

A simple spectrophotometric method was developed to determine riociguat in bulk and tablet formulation. The present method lies on the oxidation of MBTH by Fe ${ }^{+3}$ ions in acidic medium to form active coupling species and followed by its coupling with riociguat to form the chromophore having $\lambda \max 660 \mathrm{~nm}$. Validated the proposed method as per the existing guidelines of $\mathrm{ICH}$. Good linearity $(\mathrm{r} \sim$ 0.999) was observed for calibration curve in the studied concentration range $(6.25-37.50 \mu \mathrm{gL}-1)$. Reproducibility, accuracy and precision of the method were confirmed from low values of \% RSD.

Keywords: Riociguat, MBTH, Oxidative coupling, Validation, Visible spectrophotometry.

\section{INTRODUCTION}

Riociguat is used in the treatment of two types of $\mathrm{PH}$ (pulmonary hypertension) like $\mathrm{PAH}$ (pulmonary arterial hypertension) as well as CTEPH (chronic thromboembolic pulmonary hypertension) ${ }^{1}$. $\mathrm{C}_{20} \mathrm{H}_{19} \mathrm{FN}_{8} \mathrm{O}_{2}$ is the molecular formula and $422.415 \mathrm{~g} / \mathrm{mol}$ is its molar mass. Its IUPAC name is Methyl N-[4,6-Diamino-2-[1-[(2fluorophenyl)methyl]-1H-pyrazolo[3,4-b]pyridin-3yl]-5-pyrimidinyl]-N-methyl-carbaminate (Fig.1). It is non-hygroscopic with white to yellowish colour. Approval for riociguat was sanctioned in 2013 to
Bayer Healthcare Pharmaceuticals and Adempas is the brand name of it from Bayer Company. It is a potent and oral stimulator of the enzyme involved in the cardiopulmonary system like soluble guanylate cyclase (sGC) ${ }^{2}$. In addition to direct stimulating of sGC, it also improves the sensitivity of sGC towards NO. Its bioavailability is high (94.3\%) and is absorbed very quickly. Either on major CYP isoforms or transporter proteins, its effect is insignificant at the therapeutic levels. Drug interaction related clinical risks are low because of its fast clearance by multiple CYP (cytochrome P450) enzymes ${ }^{3}$.

This is an Open Access article licensed under a Creative Commons license: Attribution 4.0 International (CC- BY). Published by Oriental Scientific Publishing Company @ 2018

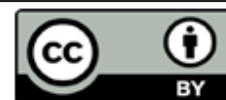


<smiles>COC(=O)N(C)c1c(N)nc(-c2nn(Cc3ccccc3F)c3ncccc23)nc1N</smiles>

Fig. 1. Chemical structure of Riociguat

Literature survey reveals the established methods for determination of riociguat by $\mathrm{UV}^{4}$,

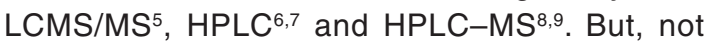
reported any visible spectrophotometric method. Well known spectrophotometric methods involve ion pair formation ${ }^{10-15}$ and oxidation ${ }^{16-20}$. Hence, an attempt was made in the current study to verify the applicability of a chromogenic coupling agent like MBTH (3-methylbenzothiazolinone hydrazone) as an analytical probe to develop as well as validate a simple visible spectrophotometric method to determine Riociguat.

\section{MATERIALS AND METHODS}

Preparation of standard riociguat drug solution

Accurately weighed and transferred an amount of $50 \mathrm{mg}$ standard drug of Riociguat in to a volumetric flask $(50 \mathrm{~mL})$. After proper dissolution of it in methanol, the solution was diluted up to the mark with the same solvent and the obtained stock solution $\left(1000 \mu \mathrm{g} \mathrm{mL}^{-1}\right)$ was further diluted suitably.

\section{Preparation of reagents}

$1 \mathrm{M} \mathrm{HCl}$ was used to prepare ferric chloride $(3 \% \mathrm{w} / \mathrm{v})$ solution. Distilled water and methanol were used respectively to prepared MBTH $(0.5 \% \mathrm{w} / \mathrm{v})$ and riociguat solutions (standard stock and working).

\section{Instrumentation}

Analytical grade chemicals were used throughout the study and solutions were prepared using distilled water. A double beam spectrophotometer (Shimadzu UV-1700) was used along with Shimadzu UV-Probe 2.10 software. Standard quartz cuvettes were used for analysis.

\section{Optimized method procedure}

$3 \mathrm{~mL} \mathrm{FeCl}{ }_{3}$ solution was added to all the flasks comprising an aliquot of standard working solution of riociguat $\left(100 \mu \mathrm{g} \mathrm{mL} \mathrm{m}^{-1}\right)$. Then $3 \mathrm{~mL}$ of MBTH solution was added. Intermittent stirring was done for $15 \mathrm{~min}$. Then made up to the mark in a $10 \mathrm{~mL}$ volumetric flask using distilled water.

\section{RESULTS AND DISCUSSIONS}

\section{Absorption Spectrum of Coloured Complex}

The established chromophore for determination of riociguat by visible spectrophotometry has a characteristic $\lambda \max$ at $660 \mathrm{~nm}$ (Figure 2).

\section{Reaction Conditions and their Optimization}

Carried out the experiments to optimize the conditions of reaction in order to obtain highest absorbance for the developed coloured solution. Intensity of the generated colour is affected by various parameters such as amount of MBTH, nature and amount of oxidant, concentration of acid, temperature, diluting solvent and order of addition of reagents. Concentrations and volumes of different reagents were fixed by varying one parameter at one time. Oxidative coupling of MBTH takes place in acidic ${ }^{21-26}$, neutral ${ }^{27}$ and basic media ${ }^{28-29}$. However, oxidative coupling of MBTH in alkaline medium is complicated ${ }^{30}$. For example, by-products formed in the oxidation of MBTH are precipitated. The referred remedies for this problem are usage of lower concentrations of MBTH or dissolving the so formed precipitate by the addition of suitable organic solvents. Another difficulty is rapid oxidation of MBTH in alkaline medium compared to acidic medium. It is prone to further oxidation of the desirable reactive coupling agent (MBTH electrophile), leading to the formation its decomposition products which are non-reactive. Therefore, the reactive form of MBTH agent (MBTH electrophile) is depleted. Hence, acidic medium is encouraging for the reaction between MBTH and less reactive molecules ${ }^{28,31}$. So, acidic medium was fixed for the reaction. Out of the available oxidants, ferric chloride and ceric ammonium sulphate are proved as more apt and are extensively employed. In the present case, ferric chloride chloride was found to be best. 


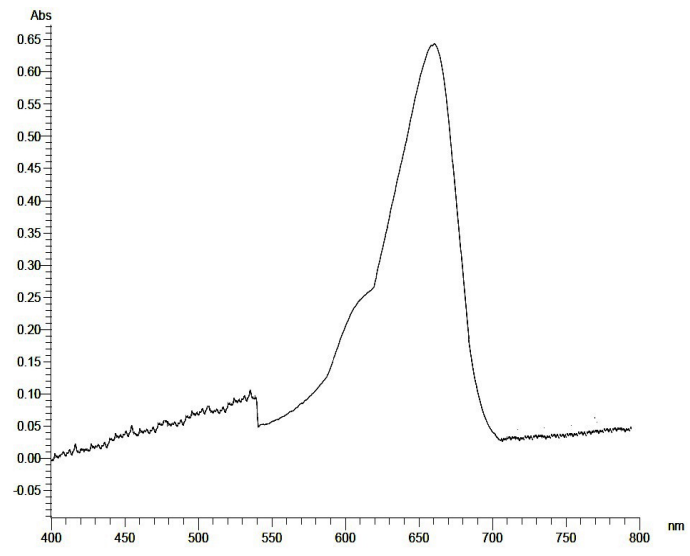

Fig. 2. Visible spectrum of Riociguat-MBTH chromophore

A decrease in the absorbance was observed with further increase of MBTH volume beyond the optimum condition. In addition to it, an increase in intensity of blank colour was also observed. It can be attributed to the participation of MBTH in self-coupling ${ }^{32}$. Similarly a fadeout of colour with an increase of oxidant concentration might be due to the oxidation of the coupling product ${ }^{30,33}$. One molar acidic condition was optimized to assist both stabilization and dissolution of ferric ions. As the intensity decreases with an increase of temperature above the room temperature, conducted the experiments at ambient temperature. As these oxidative coupling reactions (involving MBTH) were time dependent, the absorbance reached maximum at 15 minute. Acetonitrile and water gave the comparable intensity of colour but higher values compared to methanol, ethanol, isopropyl alcohol, acetone and DMSO. Water was selected as a diluting solvent based on cost and availability. Sequence of reagents addition is crucial in the colour development reaction. Based on the experiments, MBTH and oxidant were mixed prior to the addition of drug. The optimized conditions are embedded in the materials and methods section.

\section{Chromophore Formation and Chemistry}

MBTH was first synthesized by Bestom and is also known as Bestom reagent ${ }^{34}$. It is mostly used for the preparation of azo dyes. Its oxidative coupling nature was first revealed by Hunig and Fritsch in $1957^{35}$. But Sawicki et al., ${ }^{34-35}$ successfully introduced MBTH as an analytical reagent to detect as well as determine a wide range of organic compounds. Its oxidation product acts as a chromogenic agent to determine organic compounds containing active methylene groups, hetero aromatic compounds, phenols, aliphatic aldehydes, aromatic amines, indoles, carbazoles, phenothiazines, antipyrine etc $^{36}$. As the nitro group possessing drugs have poor affinity towards coupling agents, they are reduced to active amino group and then coupled with MBTH to obtain a chromophore ${ }^{22}$. In the presence of 1,2-di-(4-pyridyl)ethylene, MBTH was found to be useful to determine ozone content in the atmosphere ${ }^{37}$. Moreover, MBTH was also applied to assess the activities of different enzymes ${ }^{38-39}$, determination of carbohydrate in microalgae ${ }^{40}$ and qualitative detection as well as quantitative estimation of monosaccharides ${ }^{41}$.

In addition to the above plentiful applications, MBTH is a popular oxidative coupling agent in the estimation of phenolic/nitrogen compounds or pharmaceutical drugs bearing these functional groups in structures ${ }^{30}$. In the current study, riociguat was allowed to react with the oxidized form of MBTH (Electrophile II) to form a green coloured product (Fig. 3). Ferric chloride oxidizes MBTH (I) to form an electrophilic intermediate by the loss of two electrons and one proton. The electrophile (II) is the active coupling agent ${ }^{42}$. It participates in electrophilic substitution on riociguat to form the chromophore. Mono substitution of (II) on riociguat was confirmed from stoichiometry of 1:1 (Riociguat:MBTH) which was measured by using limiting logarithmic method ${ }^{43}$.

Substitution position on riociguat is a topic of discussion. The electrophile attacks the carbon atom having highest electron density. Literature survey shows that preferable coupling position is para to $-\mathrm{OH} /-\mathrm{NH}_{2}$ group on aromatic ring. But takes place at less sterically hindered o-position when p-position is not free ${ }^{27}$. In the present case, substitution on phenyl ring can be negated due to fluorine substitution on it which has very high electron withdrawing nature. Chances on pyrazole and pyrimidine rings can be refuted due to lack of possibility of deprotonation. The left over choice is pyridine ring. Electrophile (II) substitution on pyridyl moiety was reported earlier in the case of estimation of Lafutidine ${ }^{44}$. Similarly, electrophilic substitution of diazonium cation on isoniazid (Pyridine-4-carboxylic acid hydrazide) was reported at meta position to nitrogen ${ }^{45}$. Based on the resonance forms of pyridine, 
the plausible electrophilic substitution is shown in Figure 4.

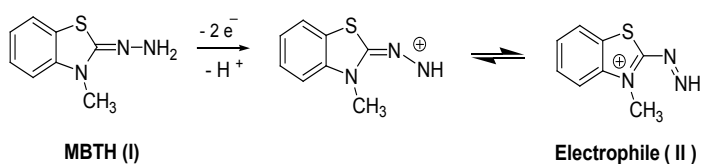

Fig. 3. Formation of electrophile $\left(\mathrm{E}^{+}\right)$

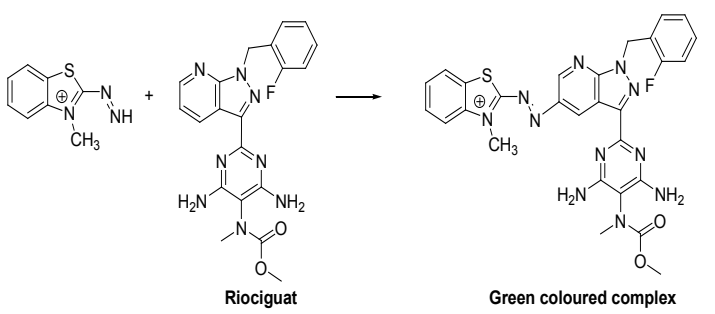

Fig. 4. Coloured complex formation between riociguat and electrophile $\left(E^{+}\right)$

\section{Validation of Method \\ Linearity and range}

Observed a linear relation for plot of absorbance against riociguat concentration (6.25$37.50 \mu \mathrm{g} \mathrm{mL}^{-1}$ ) (Fig. 5) as the correlation coefficient is high $(\sim 0.999) . y=0.026 x+0.0042$ was the linear regression equation from method of least squares. Each point existing on the linear calibration curve is a mean value for three measurements (Table 1). Various optical and regression parameters are shown in Table 2.

\section{Table 1: Calibration curve values}

\begin{tabular}{cc}
\hline Concentration $\left(\mu \mathrm{g} \mathrm{mL}^{-1}\right)$ & Absorbance* \\
\hline 6.25 & 0.1784 \\
12.50 & 0.3247 \\
18.75 & 0.4752 \\
25.00 & 0.6512 \\
31.25 & 0.8258 \\
37.50 & 0.9788 \\
\hline
\end{tabular}

\section{Accuracy}

Confirmed the accuracy of the proposed method from values of percent recovery. Added three different amounts (50\% to $150 \%)$ of riociguat sample to a constant amount $\left(12.50 \mu \mathrm{g} \mathrm{mL}^{-1}\right)$ of it so that theoretical amount (total amount) of drug concentration is maintained within the range of linearity. Values of percent recovery were found to be in the range of $99.95-100.03$ (Table 3). Established the accuracy of the method from lower values of \%RSD as well as S.D.

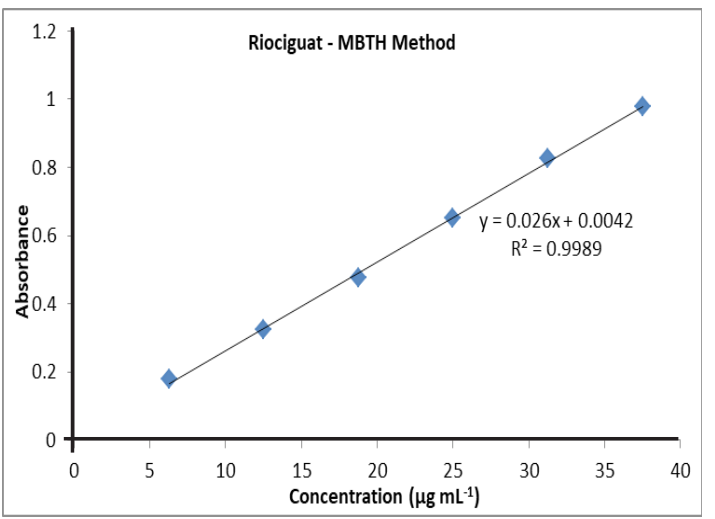

Fig. 5. Calibration graph of Riociguat

Table 2: Key parameters of method development \& validation

\begin{tabular}{lcc}
\hline S. No. & Parameter & Observation \\
& Optical characteristics & \\
\hline
\end{tabular}

\begin{tabular}{|c|c|c|}
\hline 1. & Apparent molar absorptivity $\left(\mathrm{Imol}-1 \mathrm{~cm}^{-1}\right)$ & $1.1 \times 10^{4}$ \\
\hline 2. & $\begin{array}{c}\text { Sandell's sensitivity }\left(\mu \mathrm{g} \mathrm{cm}^{-2} \mathrm{~A}^{-1}\right) \\
\text { Regression analysis }\end{array}$ & 0.0379 \\
\hline 1. & Slope & 0.026 \\
\hline 2. & Intercept & 0.0042 \\
\hline 3. & $\begin{array}{l}\text { Regression coefficient }(r) \\
\text { Validation parameters }\end{array}$ & 0.9989 \\
\hline 1. & $\lambda \max$ & $660 \mathrm{~nm}$ \\
\hline 2. & Beer's Law Limit (Linearity, $\mu \mathrm{g} \mathrm{mL}^{-1}$ ) & $6.25-37.50$ \\
\hline 3. & Limit of detection $\left(\mu \mathrm{g} \mathrm{mL}^{-1}\right)$ & 0.06 \\
\hline 4. & Limit of quantitation $\left(\mu \mathrm{g} \mathrm{mL}^{-1}\right)$ & 0.20 \\
\hline 5. & Minimum stability period & 12 hours \\
\hline
\end{tabular}

Table 3: Recovery of riociguat

\begin{tabular}{|c|c|c|c|c|}
\hline $\begin{array}{l}\text { Level of } \\
\text { recovery }\end{array}$ & $\begin{array}{l}\text { Amount of drug } \\
\text { recovered }\left(\mu \mathrm{g} \mathrm{mL}^{-1}\right)\end{array}$ & \multicolumn{2}{|c|}{$\begin{array}{l}\text { Statistical \% } \\
\text { evaluation }\end{array}$} & \multirow{2}{*}{$\begin{array}{c}\text { Recovery }= \\
\text { Practical } \times 100 / \\
\text { Theoretical }\end{array}$} \\
\hline \multirow[t]{3}{*}{50} & 18.75 & Mean & 18.75 & \\
\hline & 18.74 & SD & 0.008 & 99.95 \\
\hline & 18.76 & $\%$ RSD & 0.044 & 100.05 \\
\hline \multirow[t]{3}{*}{100} & 24.98 & Mean & 24.99 & 99.92 \\
\hline & 24.99 & SD & 0.005 & 99.96 \\
\hline & 24.99 & $\%$ RSD & 0.019 & 99.96 \\
\hline \multirow[t]{3}{*}{150} & 31.24 & Mean & 31.25 & 99.97 \\
\hline & 31.26 & SD & 0.008 & 100.03 \\
\hline & 31.25 & $\%$ RSD & 0.026 & 100.00 \\
\hline
\end{tabular}

-Nominal concentration used (a): $12.50 \mu \mathrm{g} \mathrm{mL}^{-1}$

-Amount of drug added (b): $6.25,12.50$ and $18.75 \mu \mathrm{g} \mathrm{mL}^{-1}$ respectively for $50 \%, 100 \%$ and $150 \%$ recovery levels

-Theoretical amount: Total amount of drug $(a+b)=18.75,25.00,31.25$ $\mu \mathrm{g} \mathrm{mL}^{-1}$ respectively for $50 \%, 100 \%$ and $150 \%$ recovery levels 


\section{Precision}

Satisfactory precision of the method was evident from the \%RSD values which were observed in the range of $0.005-0.013$ and $0.022-0.206$ respectively for inter-day and intraday precision studies (Table 4).

Table 4: Precision studies

\begin{tabular}{ccccc}
\hline \multicolumn{5}{c}{ Concentration* } \\
$\begin{array}{c}\text { Concentration } \\
\text { of Drug } \\
\left(\mu \mathrm{g} \mathrm{mL} \mathrm{mL}^{-1}\right)\end{array}$ & $\begin{array}{c}\text { Intraday } \\
(\text { Mean } \pm \mathrm{SD}) \\
\left(\mu \mathrm{g} \mathrm{mL} \mathrm{mL}^{-1}\right)\end{array}$ & $\begin{array}{c}\text { Inter-day } \\
(\mu \mathrm{Mean} \pm \mathrm{SD}) \\
\left(\mu \mathrm{mL}^{-1}\right)\end{array}$ & $\%$ RSD \\
\hline $\begin{array}{r}6.25 \\
18.75\end{array}$ & $\begin{array}{c}6.251 \pm 0.0008 \\
37.5\end{array}$ & 0.013 & $5.002 \pm 0.0011$ & 0.022 \\
\hline
\end{tabular}

* Average of six determinations

\section{Ruggedness}

Two analysts carried out the assay on different days following the above method to study the ruggedness. Confirmed the ruggedness of the method from the reproducible results (Table 5).
Table 5: Ruggedness of method

\begin{tabular}{rcc}
\hline $\begin{array}{l}\text { Test Concentration } \\
\text { of Drug }\left(\mu \mathrm{g} \mathrm{mL}^{-1}\right)\end{array}$ & $\begin{array}{c}\text { Concentration* } \\
\text { Analyst change } \\
\text { Mean } \pm \mathrm{SD}\left(\mu \mathrm{g} \mathrm{mL} \mathrm{mL}^{-1}\right)\end{array}$ & $\% \mathrm{RSD}$ \\
\hline 6.25 & $6.252 \pm 0.002$ & 0.032 \\
18.75 & $18.755 \pm 0.016$ & 0.085 \\
37.5 & $37.501 \pm 0.012$ & 0.032 \\
\hline
\end{tabular}

${ }^{*}$ Average of six determinations

Calculated the values of LOD and LOQ for the determination of riociguat as per the $\mathrm{ICH}$ guidelines (2005) ${ }^{46-47}$ and the corresponding values are 0.06 and $0.20 \mu \mathrm{g} \mathrm{mL}^{-1}$ respectively.

\section{Analysis of Pharmaceutical Formulations}

In view of the good recovery values of the API (Table 6), the above developed method can be applied for the determination of riociguat amount in the tablet formulations. Spectrophotometric method is used for routine analysis in QC laboratories of industries in developing countries ${ }^{48-51}$. Hence, this method can be applied to determine the quantity of riociguat present in pure and tablet formulations.

Table 6: Assay of Pharmaceutical Formulation

\begin{tabular}{lcccc}
\hline Formulation & Labeled amount $(\mathrm{mg})$ & Amount found $(\mathrm{mg})$ & $\%$ Drug Recovered & \%RSD \\
\hline Adempas $^{\circledR}$ & 1 & $1.0584 \pm 0.0002$ & 105.84 & 0.019 \\
\hline
\end{tabular}

* Average of three determinations

\section{CONCLUSION}

The proposed method is the first report on the visible spectrophotometric determination of riociguat (bulk drug and pharmaceutical dosage forms). In addition, it can be used in routine analysis as an alternative to the expensive instrumental methods.

\section{ACKNOWLEDGEMENT}

Authors are thankful to Acharya Nagarjuna University and GITAM-Bengaluru Campus for providing facilities to carry out the present research work.

\section{Conflict of interest: NIL}

\section{REFERENCES}

1. Mittendorf, J.; Weigand, S.; Alonso Alija, C.; Bischoff, E.; Feurer, A.; Gerisch, M.; Kern, A.; Knorr, A.; Lang, D.; Muenter, K.; Radtke, M. Chem. Med. Chem., 2009, 4(5), 853-865.

2. Ghofrani, H.A.; D'armini, A.M.; Grimminger, F.; Hoeper, M.M.; Jansa, P.; Kim, N.H.; Mayer, E.; Simonneau, G.;Wilkins, M.R.; Fritsch, A.; Neuser, D. N. Engl. J. Med., 2013, 369(4), 319-329.

3. Frey, R.; Becker, C.; Saleh, S.; Unger, S.; van der Mey, D.; Mück, W. Clin. pharmacokinete., 2017, 1-15.
4. Ashok, C.V.; Sailaja, B.B.; Praveen, K.A. Asian J. Pharma. Clin. Res,.., 2017, 10, 241-250.

5. Gnoth, M.J.; Hopfe, P.M.; Czembor, W. Bioanalysis., 2015, 7(2),193-205.

6. Sirisha, P.; Sharma, J.V.; Nikhitha, S.; Likitha, R.; Uday, K.B.; Durga, P.S. Int. J. Pharm. Pharm. Scie., 2016, 7, 3060-3062.

7. Temgire, P.R.; Sobia, G.; Kumar, M.V.; Sayali, W.; Mohan, S.R.; Smita, N.; Vaidhun, B. J. Pharm. Res., 2018, 12(4), 461. 
8. Grimminger, F.;Weimann, G.; Frey, R.; Voswinckel, R.; Thamm, M.; Bölkow, D.; Weissmann, N.; Mück, W.; Unger, S.; Wensing, G.; Schermuly, R.T. Eur Respir. J., 2009, 33(4), 785-792.

9. Saleh, S.; Frey, R.; Becker, C.; Unger, S.; Wensing, G.; Mück, W. Pulmonary. Circulation., 2016, 6(1_suppl), S66-S74.

10. Prasad, G.G.; Nadh, R.V.; Kiran, K.K. Asian J. Pharm. Clinical Res., 2019, 12(3) 1-5. DOI:10.22159/ajpcr.2019.v12i3.29289

11. Prasad, G.G.; Nadh, R.V.; Kiran, K.K. Int. J. Res. Pharm. Sci., 2019, 10(1).

12. Prasad, G.G.; Nadh, R.V. Int. J. Appl. Pharmaceutics., 2019, 11(1) DOI: 10.22159/ ijap.2019v11i1.30125

13. Kiran, K.K.; Nadh, R.V.; Nagoji, K.E.V. Oriental. J. Chem., 2013, 29(1), 263-269, DOI:10.13005/ojc/290142.

14. Prasad, G.G.; Nadh, R.V. Int. J. Green Pharm., 2018, 12( Sup-3/ 485).

15. Prasad, G.G.; Nadh, R.V.; Sireesha, M. Oriental. J. Chem., 2019,

16. Prasad, G.G.; Nadh, R.V.; Sireesha, M. Asian J. Pharm., 2018, 12( Sup-3).

17. Prasad, G.G.; Nadh, R.V. Res. J. Pharm. Techn., 2019, 12(3).

18. Kiran, K.K.; Nadh, R.V.; Nagoji, K.E.V. Oriental. J. Chem., 2014, 30(2), 905-10, DOI:10.13005/ ojc/300272.

19. Prasad, G.G.; Nadh, R.V. Res. J. Pharm. Techn., 2019, 12(1).

20. Prasad, G.G.;Nadh, R.V. Oriental. J.Chem., 2018, 34(6) 3112-3117. DOI: 10.13005/ojc/340656.

21. Ramachandra, B.; Naidu, N.V. Int. J. Pharm. Chem. Anal., 2017, 4(4), 117-122., DOI: 10.18231/2394-2797.2017.0026.

22. Hadi, H.; Mouayed, M. Iraqi. J. Pharm. Sci., 2017, 25(2), 7-14.

23. Reddy, K.S.; Nayak, M.H.; Naidu, N.V. Int.J. Eng., 2016, 4(S2), 39-47

24. PaniKumar, D.A.;Archana, G.;Sunitha, G.;Rachel Paul, K.; Harika, R. Pharm. Anal. Acta., 2015, 6(2), 362, doi: 10.4172/ 21532435.1000362.

25. Varsha, M.S.;Babu, N.R.;Padmavathi, Y.; Kumar, P. R. Int. Curr. Pharm. J., 2015, 4(4), 378-381.

26. Sudhir, M.S.; Nadh, R.V. Oriental. J. Chem., 2013, 29(4), 1507-1514, DOI:10.13005/ojc/290429.

27. Sastry, C.S.; Rao, A.R. Microchim. Acta[Wien]., 1989, 97(3-4), 237-244.

28. Pospíšilová, M.; Polášek, M.; Svobodová, D. Microchim. Acta., 1998, 129(3-4), 201-208.
29. Pospíšilová, M.; Svobodová, D.; Gasparic, J.; Machácek, M. Microchim. Acta., 1990, 102(1-3), 117-128.

30. Tharpa, K.; Basavaiah, K.; Revanasiddappa, H.D.; Vinay, K.B. Talanta., 2010, 81(4-5), 1216-1223.

31. Pospfsilovfi, M. Thesis, Charles University, Hradec Krfilov., 1986.

32. Chilukuri, S.P.S.; Kolli, R.R.; Davuluri, S.P. Mikrochim. Acta., 1997, 126(1-2), 167-172.

33. El Ragehy, N.A.; Abbas, S.S.; El-Khateeb, S.Z. J. pharm. Biomed. anal., 2001, 25(1), 143-151.

34. Sawicki, E.; Hauser, T.R.; Stanley, T.W.; Elbert, W. Anal. Chem., 1961, 33(1), 93-96.

35. Sawicki, E.; Stanley, T.W.; Hauser, T.R.; Elbert, W.; Noe, J. L. Anal. Chem., 1961, 33(6),707- 722.

36. Siaha, M.; Farzaeia, M.H.; Ashrafi-Kooshka, M.R.; Adibib, H.; Khodarahmi, R. A Preliminary Study. J. Rep. Pharma. Sci., 2017, 6(1), 23-33.

37. Hauser, T.R.; Bradley, D.W. Anal. Chem., 1966, 38(11), 1529-1532.

38. Setti, L.; Scali, S.; Degli Angeli, I.; Pifferi, P.G. Enzyme Microb. Technol., 1998, 22, 656-661.

39. Furnival, B.; Harrison, J.M.; Newman, J.; Upshall, D.G. Xenobiotica., 1983, 13, 361-372.

40. Van Wychen, S.; Long, W.; Black, S.K.; Laurens, L.M. Anal. biochem., 2017, 518, 90-93.

41. Anthon, G.E.; Barrett, D.M. Anal. Biochem., 2002, 305(2), 287-289.

42. El-Yazbi, A.; Mahgoub, H.; Barary, M. Bull. Fac. Pharm. Cairo Univ., 1993, 31(1), 63.

43. Alarfaj, N.A.; Altamimi, S.A.; Almarshady, L.Z. Asian J. Chem., 2009, 21(1), 216-217.

44. Reddy, M.S.; Babu, B.H. Int. J. Pharm Sci. Res., 2015, 6(6), 2626.

45. Naidu, G.K.; Suvardhan, K.; Kumar, K.S.; Rekha, D.; Sastry, B.S.; Chiranjeevi, P. J. Anal. Chem., 2005, 60(9), 822-827.

46. Sethi, P.D. CBS publications., India., 2001.

47. ICH guidelines, Text and Methodology., 2015, 2 (1), 8-13.

48. Sudhir, M.S.; Nadh, R.V. Res. J. Pharm. Biol. Chem. Sci., 2013, 4(1), 609-617.

49. Sudhir, M.S.; Mohan, M.P.; Nadh, R.V. Oriental. J. Chem., 2013, 29(1), 235-240. DOI:10.13005/ojc/290137.

50. Taraj, K.; Delibashi, A.; Andoni, A.; Lazo, P.; Kokalari, E.; Lame, A.; Xhaxhiu, K.; Çomo, A. Asian J. Chem., 2013, 25(13), 7361-7364, https://doi.org/10.14233/ajchem. 2013.14642.

51. Taraj, K.; Malollari, I.; YIli, F.; Maliqati, R.; Andoni, A.; Llupa, J. J. Agric Inf., 2018, 9(1), 41-46. doi: 10.17700/jai.2018.9.1.440 41. 